\title{
The Teacher Achievement Motivation as an Intervening Variable in Relationship between Teacher's Profesionalism, Principal's Leadership and Teacher's Performance of State High School in Banjarmasin City
}

\author{
Stefanus Damai*, Rustam Effendi, Sulaiman \\ Master of Education Management Program, Lambung Mangkurat University, North Banjarmasin, 70124, South \\ Kalimantan.
}

\begin{tabular}{|c|c|}
\hline ARTICLE INFO & A B S T R ACT \\
\hline \multirow[t]{2}{*}{$\begin{array}{l}\text { Article history } \\
\text { Received: June } \\
\text { Revised: August } \\
\text { Accepted: September } \\
\text { Keywords: Teacher profesional- } \\
\text { ism, Principal leadership, Teach- } \\
\text { er achievement, teaceher perfor- } \\
\text { mance }\end{array}$} & $\begin{array}{l}\text { The aim of this research is to describe the relationship between teacher profes- } \\
\text { sionalism, headmaster leadership, and teachers' performance through the inter- } \\
\text { vening variable which is the teachers' achieving motivation. This research was } \\
\text { done with the quantitative method with } 228 \text { teachers as the samples who were } \\
\text { from the I } 3 \text { different Senior High Schools in Banjarmasin based on random } \\
\text { sampling. Data is taken with the checked questionnaire for its validity and relia- } \\
\text { bility based on the pilot project. Data were analyzed by path analysis with calcu- } \\
\text { lations through IBM SPSS } 20 \text {. The results showed that there was a relationship } \\
\text { between teacher professionalism, principals 'leadership, and teacher performance } \\
\text { and achievement motivation was intervening between the relationship between } \\
\text { teacher professionalism and teacher performance and principals' leadership and } \\
\text { performance. }\end{array}$ \\
\hline & $\begin{array}{l}\text { CC) (7) } 2019 \text { The Authors. Journal of K6, Education, and Management } \\
\text { (j-K6EM). ISSN: 2580-2135. Published by Graduated Program of } \\
\text { Educational Management, UniversitasLambungMangkurat, Ban- }\end{array}$ \\
\hline
\end{tabular}

*Correspondence: Stefanus Damai; E-mail: 1) adadamai@yahoo.com, 2) damaistefanus@gmail.com

\section{Introduction}

The development of education, in general, must be emphasized in efforts to improve the quality of education which has implications for improving the quality of personal and community life. This is in line with what is stated in Law No. 20 of 2003 concerning the
National Education System, that the goal of national education is to educate the nation's life and develop Indonesian people as a whole, namely human beings who believe and devote to the Almighty God and have noble character, have knowledge and skills, physical and spiritual health, a solid and independent personali- 
ty and a sense of responsibility for life in the community, nation and state.

Furthermore, Law Number 20 of 2003 concerning the National Education System states that "education is a conscious and planned effort to create a learning atmosphere and learning process so that students actively develop their potential to have spiritual power". The education sector has a very important role in the development period national because education is an effort to improve the quality of human resources. Some studies show that educational background has a significant influence on the quality of workers (cf. (Ishola, Adeleye, dan Tanimola, 2018; (Kotur \& Anbazhagan, 20I4). Likewise in the world of education, the educational background also influences teacher professionalism (Cansoy \& Parlar, 2017) where teachers often learn and train themselves, they will have better teaching skills (Gore, et al., 2017).

One of the main factors that determine in improving the quality of education is teacher performance. Student achievement is influenced by the effectiveness of learning by teachers (Selamat, Samsu, dan Kamalu, 2013) (Gichuru \& Ongus, 2016). The quality of learning delivered by the teacher has a positive and significant effect on student achievement (Darling-Hammond, 2000). In addition to the implementation of learning student learning outcomes are also influenced by the educational qualifications of teachers who teach (Batool, Tahir, \& Habib, 2018). Furthermore, it was found that qualifications are not only academic qualifications that play a role in student academic achievement but more than that the personal qualifications of teachers have a more important role (Kola \& Sunday, 2015). So, it can be said that teachers are the main factor in the education process. Although the educational facilities are complete and sophisticated, but if not supported by the existence of the qualified teacher the maximum learnin process will be not happened (Utami, 2003).

The effectiveness of the teacher's work will be achieved if the teacher has high morale that has an impact on the learning process of students who are getting better. Regarding performance, Simanjuntak (Susanto, 2016) explains that performance is "The level of achievement of results for the implementation of certain tasks in order to achieve organizational goals". In this case, Simanjuntak emphasizes that performance is important and urgent in achieving organizational goals because every individuals or organization have goals to be achieved by setting goals.
The Prawirosentono (Susanto, 2016) defines performance as "The work that can be achieved by a person or group of people in an organization, in accordance with their respective authorities and responsibilities in an effort to achieve the objectives of the organization legally, not violating the law and in accordance with the moral and law ". Furthermore, regarding the performance of Armstrong and Baron (Suriansyah, 2014) explained that performance is "Implementation of work and results of implementation carried out by someone about what is done and how to do it".

Teacher performance is reflected in learning outcomes or achievements achieved by students. Professional teacher performance will result in high learning achievement. Therefore, realizing the importance of teacher performance, efforts were made to improve performance, including supervision, scientific activities, further studies, and teacher performance evaluations.

Teachers are the educational staff who have the main task to educate, teach, train, and direct students to have readiness in facing increasingly fierce global competition with other countries. Therefore, the position of the teacher as a professional is very important in the realization of the vision and mission of the implementation of learning in the education unit where he performs his duties. Professional teachers are teachers who prioritize quality and service quality. Teacher services must meet the standards of the needs of the people, the nation, and users and maximize the ability of students based on the potential and skills of each individual. To become a professional teacher must have several competencies.

The performance of a teacher is said to be good if the teacher has done the elements which consist of loyalty and high commitment to the task of teaching, mastering and developing learning material, discipline in teaching and other assignments, creativity in teaching, collaboration with all school members, leadership being a student role model, a good, honest, and objective personality in guiding students, as well as responsibility for their duties.

In their duties, the teacher will certainly face various challenges and problems. Such conditions require that the teacher can create and maintain optimal learning conditions and control them if a disruption occurs in the learning process. To deal with these problems, the professionalism of a teacher is very necessary. The demands and development of teacher professionalism are a global concern because teachers have the duty and role not only to provide information on science and technology but also to shape attitudes and souls that 
are able to survive in the era of competition or high competition.

The teacher's job is to help students adapt to various life challenges and the insistence that develops in them. Empowerment of students includes aspects of personality, intellectual, social, emotional, and skill aspects.

Professional teachers are teachers who want to prioritize quality and quality of services and products, teacher services must meet the standards of the needs of the community, the nation, and users and maximize the ability of students based on the potential and skills of each student. To become a professional teacher must have several competencies in the Teacher Law and Lecturer No.I4 Year 2005 and Government Regulation No.I9 of 2005, namely: personality competence; pedagogic competence; professional competence; and social competence.

Furthermore, the above matters are closely related to other matters such as achievement motivation. Achievement motivation was introduced by Murray which was termed the need for achievement and popularized by McClelland (I96I) as "n-ach", who assumed that achievement motives were mental viruses because they were thoughts related to how to do activities better than ever done before.

If someone has contracted this virus, the individual behavior becomes more active and individuals become more active in doing activities to achieve better performance than before. Achievement motivation has a very important role in efforts to achieve academic achievement (Kumari \& Qasim, 2015). Not only in terms of academic achievement, but several studies also show that achievement motivation also has an influence on one's performance in carrying out their duties (cf. Mahmoudi, Rostami, Mahmoudjanloo, \& Jahani, 2017; Kanfer, Frese, \& Johnson, 2017). Individuals who show achievement motivation according to McClelland are those who are task oriented and are ready to accept tasks that are challenging and often evaluate their tasks in several ways, namely comparing with the work of others or with certain standards.

In addition, McClelland (I987) also defines achievement motivation "as a standard of excellence, namely the tendency of individuals to achieve achievement optimally". Furthermore, according to Haditono (Kumalasari, 2006), achievement motivation is the tendency to achieve in relation to the standard value of excellence.

This achievement motivation makes achievement as the goal itself. Individuals who are motivated for achievement do not reject the award; do not really feel happy if in heavy competition he succeeds in winning it with hard work after reaching the specified standard.

Individuals who have high achievement motivation generally like to create soft risks that can require considerable admiration and hope for valuable results, skills, and determination that show a reasonable possibility rather than the results achieved by mere profits. If starting a job, individuals who have high achievement motivation want to know how their work is; they prefer activities that provide fast and precise feedback.

According to Herman (Linda, 2004) "this achievement motivation is very important in the everyday life, because the motives for achievement will encourage someone to overcome challenges or obstacles and solve one's problems, compete in a healthy manner, and will affect one's work performance."

Atkinson (Martaniah, 1998) said that "Motivation for achievement in individual behavior contains two behavioral tendencies, namely: a. Individuals who tend to pursue or approach success b. Individuals who try to avoid failure."

Based on the Article I2 paragraph (I) Government Regulation Number 28 of 1990 states that "Principals are responsible for organizing educational activities, school administration, fostering other education personnel and utilizing and maintaining facilities and infrastructure" (Susanto, 2016).

The headmaster is a determining factor in managing education at school in order to achieve educational goals. Therefore, principals are required to have adequate knowledge, abilities, and skills. The principal as the highest leader in the school is very influential and determines the progress of the school must have administrative skills, high commitmentand flexible in carrying out their duties. Good communication between principals, teachers, and students is important in realizing learning objectives in schools (Sahenk, 2010).

A good headmaster's leadership must be able to strive to improve teacher performance through an education staff capacity building program. Therefore, the principal must have a personality or the characteristics and abilities and skills to lead an educational institution. Good leadership will provide a positive influence on the performance of employees (Hao\&Yazdanifard, 2015). In addition, in the world of work leadership style also influences work motivation in teams (Rahbi, Khalid, \& Khan, 2017)

In his role as a leader, the headmaster must be able to pay attention to the needs and feelings of the people who work so that the teacher's performance is always 
maintained. The principal as one of the managers of the education unit is also referred to as an administrator and is also referred to as an education manager.

The headmaster as a manager is the key holder of school back and forth. This is in line with the opinion of Richardson and Barbe (Susanto, 2016: 79) which states "Principals are perhaps the most significant single factor in establishing an effective school," namely that principals are the most important factor in forming an effective school. In his position as administrator and manager of education, principals are expected to have professional skills and adequate skills. The skills needed in achieving school success are conceptual skills, relationship skills, and technical skills. Conceptual skills include the ability to see schools and all educational programs as a whole.

Human relations skills include the ability to establish effective and efficient cooperative relationships with school personnel, both individually and in groups. Technical skills are the skills and expertise that the headmaster must possess including methods, processes, procedures, and class management techniques.

With the ability of education management professionals, headmasters are expected to be able to develop effective school programs, creating a school climate

Conducive and building the performance of personnel and can guide teachers to carry out the learning process. At school, headmaster always interacts with teachers, monitor, and assess their daily activities. In carrying out the task of educating them, teachers have different traits and behaviors, some are enthusiastic and full of responsibility, besides that, there are also teachers who often skip school, come in on time and do not comply with school orders and regulations
That teacher condition becomes a problem in every formal education institution. With the existence of teachers who have low performance, the school will find it difficult to achieve the results as expected. The performance will be achieved when the principal conducts coordination, communication, and supervision on a regular basis.

Mulyasa (Taniredja, and friends, 2016:I) explained that "in accordance to do its duties at the best condition, professional, and can be accounted for; the teacher has to own the steady, stable, and mature personality."

\section{Methodology}

The populations in this study were high school teachers in Banjarmasin who numbered 528 people. The study sample was 228 teachers in 13 schools selected by random ramp. Data was collected by distributing Likert scale model questionnaires that have been tested for validity and reliability by choosing between one and five answers that best match the actual conditions.

There are four questionnaires used in this study, namely the teacher professionalism questionnaire, the principal's leadership questionnaire, the teacher's achievement motivation questionnaire, and the teacher's performance questionnaire. In accordance with the conceptual relationship model between variables, the relationship between the four variables in this study can be described as shown below.

To see the trend of each variable, the ideal average score of the research subjects with a real average, grouped into five categories as follows:

Table I. Ideal Average Research Subjects with Reality averages

\begin{tabular}{clll}
\hline No. & \multicolumn{1}{c}{ Criteria } & Category \\
\hline I. & $>$ Mi+25SDi & Really High & \\
\hline 2. & Mi+SDi $<\mathrm{X}<\mathrm{Mi}+25$ & High \\
\hline 3. & Mi-SDi $<\mathrm{X}<\mathrm{Mi}+\mathrm{SDi}$ & Average & \\
\hline 4. & Mi-25SDiX $<$ Mi_SDi & Low & \\
\hline 5. & $<$ Mi-25SDi & Really low & \\
\hline
\end{tabular}

The data analysis in this study uses simple linear regression analysis, multiple regression, and partial correlation. The validity of the instrument was tested using an item score correlation with the total score using Product Moment correlation and its reliability using Cronbach Alpha, the data analysis technique used path analysis. Analysis prerequisite test consisted of normality test and linearity test.

\section{Findings and Discussion}

\section{The Description of Research Result Data}

In accordance with the results of data processing research results, namely descriptive statistics with calculations using IBM SPSS with the results given in table 4.2 shows that the total amount of data $(\mathrm{N})$ is the same as 215 which is the result of reduction data containing data outliers. 
Table 2. Descriptive Statistics of Research Data

\begin{tabular}{lccccccc}
\hline \multicolumn{1}{c}{ Variable } & $\mathrm{N}$ & Range & Minimum & Maximum & Average & Deviation Stand- & Variance \\
\hline Teacher Professionalism & $2 \mathrm{I} 5$ & 45,00 & $\mathrm{II} 8,00$ & $\mathrm{I} 63,00$ & $\mathrm{I} 4 \mathrm{I}, 52$ & $8, \mathrm{I} 6$ & 66,60 \\
\hline Headmaster leadership & $2 \mathrm{I} 5$ & 76,00 & $\mathrm{I} 28,00$ & 204,00 & $\mathrm{I} 66,94$ & $\mathrm{I} 3,39$ & $\mathrm{I} 79,37$ \\
\hline AchievementMotivation & $2 \mathrm{I} 5$ & 47,00 & 62,00 & $\mathrm{I} 09,00$ & 87,07 & $9,2 \mathrm{I}$ & 84,79 \\
\hline Teacher Performance & $2 \mathrm{I} 5$ & 61,00 & $\mathrm{I} 25,00$ & $\mathrm{I} 86,00$ & $\mathrm{I} 56,02$ & $\mathrm{I} 2,46$ & $\mathrm{I} 55, \mathrm{I} 6$ \\
\hline
\end{tabular}

Based on the table above, the highest range or data range is 76 which is the principal's leadership data while the lowest data is 45 which is teacher professionalism data, the lowest minimum data is $6 \mathrm{I}$ which is the highest achievement motivation data is 128 which is the head leadership data school, the lowest maximum data is 109 which is the highest achievement motivation data while the data is 186 which is teacher performance data.

The highest average is the headmaster's leadership data which is 166.94 while the lowest is achievement motivation data which is 87.07 . The highest standard deviation data is the principal's leadership data which is I3.39 while the lowest is teacher professionalism which is 8.16. As for variance, the lowest data is 66.60Which is teacher professionalism while the highest data is 179.37 which is the leadership of the headmaster?

Furthermore, by utilizing the descriptive statistics above, each data on teacher professionalism, principal leadership, achievement motivation, and teacher performance will be described in the distribution table of the tendency of data to divide into very low, low, medium, high and very high groups.

\section{Teacher Profesionalism}

Teacher professionalism has a tendency in the medium category as shown in the table below:

Table 3. Teacher Profesionalism Distribution Trend

\begin{tabular}{ccccc}
\hline No. & Interval Class & F & $\%$ & Category \\
\hline $\mathrm{I}$ & $\mathrm{X} \geq \mathrm{I} 90,67$ & 0 & 0 & Really High \\
\hline 2 & $\mathrm{I} 6 \mathrm{I}, 33 \leq \mathrm{X} \leq \mathrm{I} 90,67$ & 0 & 0 & High \\
\hline 3 & $\mathrm{I} 02,67 \leq \mathrm{X} \leq \mathrm{I} 6 \mathrm{I}, 33$ & $2 \mathrm{I3}$ & $99, \mathrm{I}$ & Average \\
\hline 4 & $73,33, \leq \mathrm{X} \leq \mathrm{I} 02,67$ & 2 & 0,9 & Low \\
\hline 5 & $\mathrm{X} \leq 73,33$ & 0 & 0 & \\
\hline
\end{tabular}

Based on the table above, it is known that teacher professionalism is very high at $0(0 \%)$, high at $0(0 \%)$, medium for $213(99.1 \%)$ low at $2(0.9 \%)$, very low at $0(0 \%)$.

Table 4. Distribution of Headmaster Leadership Trend

\begin{tabular}{ccccc}
\hline No. & Interval Class & F & $\%$ & Category \\
\hline $\mathrm{I}$ & $\mathrm{X} \geq \mathrm{I04,00}$ & 0 & 0 & Really High \\
\hline 2 & $88,00 \leq \mathrm{X} \leq \mathrm{I04}, 00$ & 0 & 0 & High \\
\hline 3 & $56,00 \leq \mathrm{X} \leq 88,00$ & $2 \mathrm{I} 5$ & $\mathrm{I} 00$ & Average \\
\hline 4 & $40,00 \leq \mathrm{X} \leq 56,00$ & 0 & 0 & Low \\
\hline 5 & $\mathrm{X} \leq 40,00$ & 0 & 0 & Really Low \\
\hline
\end{tabular}

Based on the table above it is known that the leadership of the principal is very high at $0(0 \%)$, high at 0
$(0 \%)$, medium at $24(100 \%)$ low at $0(0 \%)$, very low at $0(0 \%)$.

Table 5. Distribution of Trends in Teacher Achievement Motivation

\begin{tabular}{ccccc}
\hline No. & Interval Class & F & $\%$ & Category \\
\hline $\mathrm{I}$ & $\mathrm{X} \geq \mathrm{I} 73,33$ & 2 & 0,9 & Really High \\
\hline 2 & $\mathrm{I} 46,67 \leq \mathrm{X} \leq \mathrm{I} 73,33$ & $\mathrm{I} 67$ & 77,7 & High \\
\hline 3 & $93,33 \leq \mathrm{X} \leq \mathrm{I} 46,67$ & 46 & $2 \mathrm{I}, 4$ & Average \\
\hline 4 & $66,67 \leq \mathrm{X} \leq 93,33$ & 0 & 0 & Low \\
\hline 5 & $\mathrm{X} \leq 66,67$ & 0 & 0 & \\
\hline
\end{tabular}


Based on the table above, it is known that teacher achievement motivation is very high in the amount of 2
(0.9\%), high of $167(77.7 \%)$, medium of $46(21.4 \%)$ low of $0(0 \%)$, very low equal to $0(0 \%)$.

Table 6. Distribution of Teacher Performance Trends

\begin{tabular}{ccccc}
\hline No. & Interval Class & F & $\%$ & Category \\
\hline $\mathrm{I}$ & $\mathrm{X} \geq \mathrm{I} 82,00$ & 0 & 0 & Really High \\
\hline 2 & $\mathrm{I} 54,00 \leq \mathrm{X} \leq \mathrm{I} 82,00$ & 0 & 0 & High \\
\hline 3 & $98,00 \leq \mathrm{X} \leq \mathrm{I} 54,00$ & 96 & 44,7 & Average \\
\hline 4 & $70,00 \leq \mathrm{X} \leq 98,00$ & $\mathrm{II}$ & 54,0 & Low \\
\hline 5 & $\mathrm{X} \leq 70,00$ & 3 & $\mathrm{I}, 4$ & Really Low \\
\hline
\end{tabular}

Based on the table above it is known that the teacher's performance is very high by $0(0 \%)$, high by 0 (0\%), medium by 96 (44.7\%) low by II6 (54.0\%), very low by 3 (I.4\%).

\section{Model I Path Coefficient}

Referring to the "I" mode regression output in the SubstructuralCoefficients table, it can be seen that the significance values of the two variables, XI $=0,000$ and $X 2=0,000$, are smaller than 0.05 . These results provide the conclusion that regression mode I, ie varia- bles XI and X2 have a significant relationship to $\mathrm{Z}$. The magnitude of the $\mathrm{R} 2$ or $\mathrm{R}$ square value found in table 4.I0 of the Summary Model is equal to 0, 093, this shows that the contribution of XI and X2 to Z is $9 \%$ while the remaining $91 \%$ is a contribution from other variables not included in the research variable. Meanwhile, for the value of eI it can be searched with the formula eI $=\Pi(I-0,093)=0.952$. Thus the path diagram of the structure I model is obtained as follows:

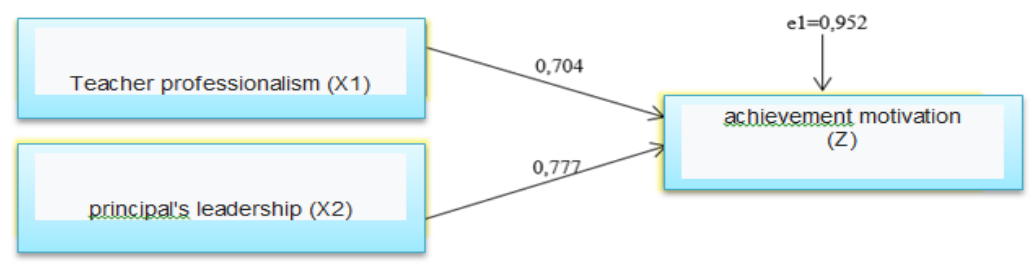

Picture I. Structure I Path Model

\section{Path Model II Coefficient}

Based on the mode II regression output in the Substructural Coefficients table Second, it can be seen that the significance values of the two variables are XI $=0.019$ and $\mathrm{X} 2=0.000$, and $\mathrm{Z}=0.020$ smaller than 0.05 . This result gives the conclusion that regression mode II, namely variables XI and X2 and Z have a significant relationship to $\mathrm{Y}$. The value of $\mathrm{R} 2$ or $\mathrm{R}$ square contained in the Model summary table is equal to 0.530 , indicating that the contribution or contribution of XI, X2, and $\mathrm{Z}$ to $\mathrm{Y}$ is $53 \%$ while the remaining $47 \%$ is the contribution of other variables not included in the research variable. Meanwhile, for the value of $\mathrm{e} 2=\square(\mathrm{I}-0,530)=0.686$, the path diagram of the structure model II is obtained.

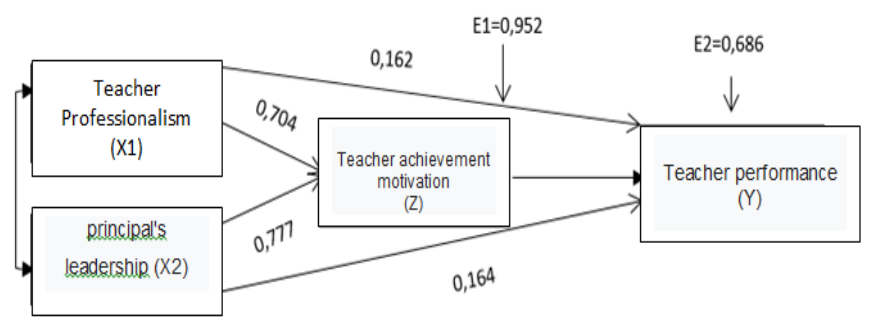

Picture 2. Structure 2 Path Model 


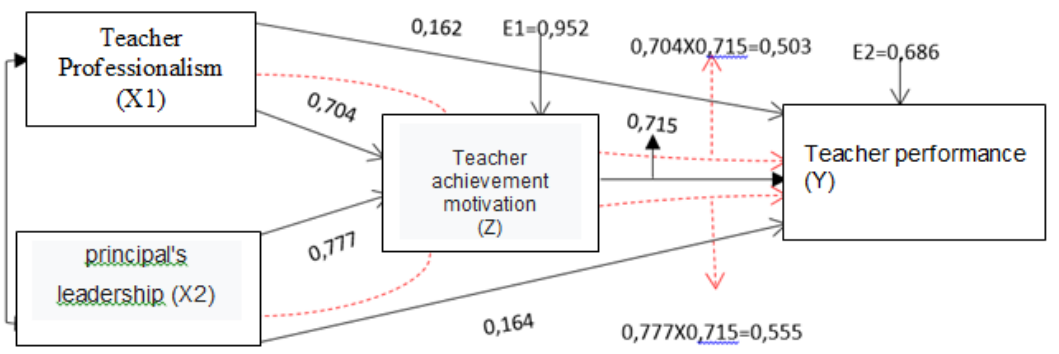

Picture 3. Final Relationship between Variables

From the picture above, direct relationships, indirect relationships, and total relationships can be determined as follows:

\section{Direct Relationship}

A direct relationship is a relationship between variables $\mathrm{XI}, \mathrm{X} 2$, and Z, then the relationship between variables
$\mathrm{XI}, \mathrm{X} 2$, and $\mathrm{Y}$ and the relationship between variables $Z$ and $Y$ variables, is simply presented as follows:

The relationship between XI and $Z=0.704$

The relationship between $\mathrm{X} 2$ and $Z=0.777$

The relationship between XI and $Y=0.162$

The relationship between $X 2$ and $Y=0.164$

The relationship between $Z$ and $Y=0.715$

Table 7. Summary of Results of Testing Direct Hypotheses

\begin{tabular}{clccc}
\hline No. & \multicolumn{1}{c}{ Hyphothesis } & P & Conclusion \\
\hline I. $\begin{array}{l}\text { There is no direct relationship between professionalism of } \\
\text { teachers and the performance of teachers of public high } \\
\text { schools in Banjarmasin City. }\end{array}$ & 0,162 & 0.00 & Reject \\
\hline 2. $\begin{array}{l}\text { There is no direct relationship between the headmaster's } \\
\text { leadership and the teacher's performance in the State High } \\
\text { School in Banjarmasin City }\end{array}$ & 0,164 & 0.00 & Reject \\
\hline T. $\begin{array}{l}\text { There is no direct relationship between teacher profession- } \\
\text { alism and achievement motivation of high school teachers } \\
\text { in Banjarmasin City. }\end{array}$ & 0,704 & 0.000 & Reject \\
\hline $\begin{array}{l}\text { There is no direct relationship between principal leadership } \\
\text { and high school teachers' achievement motivation in Ban- } \\
\text { jarmasin City. }\end{array}$ & 0,777 & 0.000 & Reject \\
\hline There is no direct relationship between teacher achievement \\
motivation and teacher performance in Banjarmasin City \\
Public High School
\end{tabular}

From the summary above, it can be seen that, first, there is a direct relationship between teacher professionalism and teacher performance in State High Schools in Banjarmasin City. Professional teachers certainly have pedagogical, social, and personal competencies that must be possessed by a teacher. So that the higher the level of professionalism of a teacher, the better the performance (Novozhenina\&Pinzón, 2018).

Furthermore, professionalism is shaped by knowledge and experience, so that the more knowledge and experience a teacher has, the more professional he will be in his field. Awareness of knowledge and experience will affect teacher performance, where the more knowledge and experience a teacher has, the better the salary will be (Makovec, 20I8).

Secondly, there is a direct relationship between the leadership of the headmaster and the performance of teachers in state high schools in the city of Banjarma$\sin$.

This is because the management skills, attitudes, and communication carried out by the headmaster will affect the performance of the teachers they lead 
(Hasbay\&Altındag, 2018). Good communication between the headmaster and the teacher will result in a comfortable working environment and situation. The more teachers feel comfortable with their work environment and work, the higher their performance (Chamundeswari, 2013).

More specifically, the instructional and delegate leadership implemented by a headmaster will affect teacher performance (Chen, 2017). This means that the ability of a headmaster in giving orders and delegating work which is essentially the ability to communicate work to the subject will affect the performance of his subordinates, the teachers. In addition, the leadership of the headmaster is well supported by competent teachers who will be able to produce outstanding students (Wahyuddin, 2017).

Third, there is a direct relationship between achievement motivation and teacher professionalism in State High Schools in Banjarmasin City. The professionalism of a teacher is shown through the teacher's performance and the performance of a teacher can be seen from how he carries out the teaching and learning process. In other words, the professionalism of a teacher can be seen from the teacher's performance. The results showed that achievement motivation and professionalism of a teacher would result in good teacher performance. That is, the higher the achievement motivation and professional level of a teacher, the higher the teacher's performance (Hasbullah\&Moeins, 2017).

Furthermore, if teachers have high motivation in carrying out their duties, the quality of learning will be better (Akuoko, Dwumah, \& Baba, 2012). With the motivation of teachers who are able to create better learning, student achievement will also increase (Taştan, et al., 2018) s. Factors that can form a teacher's achievement motivation internally are self-respect, responsibility, and the desire to complete. The work and involvement in school activities (Iliya \& Ifeoma, 2015).

Fourth, there is a direct relationship between headmasters 'leadership and high school teachers' achievement motivation in Banjarmasin City. With a good leadership style, a school headmaster will be able to make teachers who are led to have the desire to carry out their tasks well. This means that good leadership from the headmaster will foster the achievement motivation of the teachers he leads (Eyal \& Roth, 20II).

Job satisfaction resulting from good headmasters' leadership is also a factor that makes teachers more committed to their work (Wahab, Fuad, Ismail, \& Majid, 20I4).

Furthermore, supervision carried out by the headmaster can also be a source of motivation for teachers to carry out their tasks better (Gultom, Siburian, \& Purba, 2017). In addition to supervision, the achievement motivation of a headmaster is also able to motivate teachers to become effective teachers (Renata, Wardiah, \& Kristiawan, 2018).

Fifth, there is a direct relationship between teacher achievement motivation and teacher performance in Banjarmasin City Public High School. The motivation for achievement will move teachers to always do better for their students, which is to do better learning (Sivakumar, 2016). Thus, achievement motivation will affect the pedagogic abilities of a teacher (Rubayhan\&Sowiyah, 2018).

Furthermore, teacher performance in the teaching and learning process is influenced by internal and external motivation (Tehseen \& Hadi, 2015). One of the internal factors that can affect the performance of a teacher is the ability of the field of study. If the teacher has a good understanding of the field of study or material to be taught, the teacher's performance will be good (Ahmed, et al., 2012); While examples of external factors that can be external motivations are comfortable to work situations that are created from the interpersonal relationships of school people. Thus, work situations and interpersonal relationships between all school members are also important factors that influence the performance of a teacher (Kirimi, Gikunda, Obara, \&Kibett, 2013).

\section{Indirect Relation}

The indirect relationship between exogenous and endogenous variables through intervening variables can simply be presented as follows:

The indirect relationship between XI and Y through $Z=0.704 \times 0.715=0.503$

The indirect relationship between $\mathrm{X} 2$ and $\mathrm{Y}$ through $Z=0.777 X 0.715=0.555$.

Table 8 Indirect Relation

\begin{tabular}{llll}
\hline No & Hypothesis & Relation Coefficient $(B)$ & Conclusion \\
\hline
\end{tabular}




\begin{tabular}{lllll}
\hline \multicolumn{1}{c}{ There is no indirect relationship be- } & Direct & Indirect & Reject \\
tween teacher professionalism and & & $0,704 \times 0,715=0,503$ & \\
teacher performance through teacher & & \\
high school achievement motivation in & & \\
Banjarmasin City. & & & Reject \\
7. There is no indirect relationship be- & & \\
tween the headmaster leadership and \\
teacher performance through teacher \\
high school achievement motivation in \\
Banjarmasin City.
\end{tabular}

\section{The Total Relation}

The total relationship is the sum between direct relations and indirect relationships, namely as follows: The total relationship between XI and Y $=0.162+$ $0.503=0.665$

The total relationship between $\mathrm{X} 2$ and $\mathrm{Y}=0.164+$ $0.555=0.719$

Data from the calculation of distribution by grouping very high, high, medium, low, and very low for teacher professionalism. The tendency of data for teacher professionalism is very high at $0(0 \%)$, high at $0(0 \%)$, medium for $2 \mathrm{I} 3(99.1 \%)$ low at $2(0.9 \%)$, very low at $0(0 \%)$. The tendency of the largest grouping data is in the medium category, which is $99.1 \%$.

Taniredja, et al. (2015) who stated that professionalism refers to the attitude of the members of the profession to their profession and the degree of knowledge and expertise they have in order to do their jobs.

The tendency of high school headmaster category data is $0(0 \%)$, high is $0(0 \%)$, medium is 215 $(100 \%)$ low is $0(0 \%)$, very low is $0(0 \%)$. The tendency of the largest grouping data is in the medium category which is equal to $100 \%$.

The headmaster leadership is an ability and readiness of the principal to influence, guide, direct and mobilize school staff to be able to work effectively in order to achieve predetermined educational and teaching goals, or it can be said that the assistance provided by the headmaster to achieve educational goals.

This is also in line with the Directorate of Dikmenum (Zazim, 20I4) which explains that educational leadership is a leader in educational institutions, including principals. The principal who is the highest leader in the school is very influential, even very decisive towards the quality of education in school. Principal leadership is the way or effort of the principal in influencing, encouraging, guiding, directing, and mobilizing teachers, staff, students, parents, and other par- ties involved to work, play a role in achieving the stated goals.

Furthermore, it is known that teacher achievement motivation is very high at $2(0.9 \%)$, high at 167 $(77.7 \%)$, medium at $46(21.4 \%)$ low at $0(0 \%)$, very low at $0(0 \%)$. The tendency of the largest grouping data is in the high category, amounting to $77.7 \%$. This proves that teacher achievement motivation in Banjarmasin City Public High School is good.

The descriptive statistical findings on achievement motivation variables state that overall teachers in Banjarmasin City Public High School believe that achievement motivation plays an important role in improving their performance. A teacher certainly has a desire to always excel. In this case, a good ability to provide teaching to students can be said as an achievement. To realize this, a teacher needs to motivate himself continuously.

This finding, in line with McClelland (Uno \& Lamatenggo, 2015: II9) states that: "People who really are able to motivate themselves to always have achievements have the following characteristics: (I) They prefer to solve problems independently. They develop the tasks they face even though they can work with others. They consider problem-solving to be a form of responsibility that must be done. (2) People who really can motivate tend to go to that situation when they can immediately get feedback on the results of their work. (3) The person who succeeds is the person who determines the objectives that contain the risk so that he can expand the opportunity to satisfy the results of his work. "

Then the teacher's performance is categorized very high by $0(0 \%)$, high by $0(0 \%)$, medium by 96 (44.7\%) low by II6 (54.0\%), very low by 3 (I.4\%). From the table above it is known that the tendency of the largest grouping data is in the low category of $54.0 \%$. This proves that in fact the performance of the teachers of public high schools in the city of Banjarmasin still needs to be improved. 
Descriptive statistics find that the level of achievement of teacher performance results in the national senior high school in Banjarmasin City in general, is in the low category which is equal to $54.0 \%$. This fact occurs because the teachers realize that good performance is important for achieving organizational goals

This is in line with the opinion of Simanjuntak (2005: 56) which states that performance is something important in order to achieve organizational goals because each individual or organization has a goal to be achieved by setting targets or targets. The success of individuals or organizations in achieving these targets or targets, that is what is performance.

Teacher performance is reflected in learning outcomes or achievements achieved by students. Professional teacher performance will result in high learning achievement.

Therefore, realizing the importance of teacher performance, efforts were made to improve performance, including supervision, scientific activities, further studies, and teacher performance evaluations. Assessment of teacher performance can provide information about weaknesses, limitations, and shortcomings of teachers in teaching, both personally and professionally. Based on the assessment data on performance, steps can be determined to improve performance. Teachers as professional educators are required to always carry out learning tasks as well as possible. Teachers must be able to demonstrate constructive and effective performance in teaching because it will have a positive impact on student learning achievement.

Sinambela (Suhaimi 2018) explains that work achievement is an implementation of a balance theory which says that a person will show optimal performance if he gets benefits and there is a fair and reasonable stimulus in his work. Optimal work performance will be achieved if there is a sense of justice felt by employees.

Hamalik (2003: 9) states that improving the quality of education must be supported by improving the quality of education staff. Education staff is an important component in the implementation of education, which is tasked with organizing teaching, training, researching, developing, managing and providing technical services in the field of education.

Teachers are educational staff who have the main task to educate, teach, train, and direct students to have readiness in facing increasingly fierce global competition with other countries. Therefore, the position of the teacher as a professional is very important in the realization of the vision and mission of the implementation of learning in the education unit where he performs his duties.

\section{Conclusion and Recommendation}

The path analysis results which have been outlined in the summary of the path analysis results are then used to answer the research hypotheses, both direct hypotheses and indirect hypotheses with a summary table as follows:

I. There is a direct relationship between the professionalism of teachers and the performance of high school teachers in Banjarmasin.

2. There is a direct relationship between the leadership of the headmaster and the performance of high school teachers in Banjarmasin.

3. There is a direct relationship between the professionalism of teachers and the achievement motivation of high school teachers in Banjarmasin.

4. There is a direct connection between the headmaster's leadership and SMAN teacher's achievement motivation in Banjarmasin.

5. There is a direct relationship between teacher achievement motivation and the performance of high school teachers in Banjarmasin.

6. There is an indirect relationship between teacher professionalism and teacher performance through high school teacher achievement motivation in Banjarmasin.

7. There is an indirect relationship between the headmaster's leadership and teacher's performance through the achievement motivation of high school teachers in Banjarmasin.

Based on this research result, it can be described that to keep or increase teacher performance, we need to increase professionalism as well. Professionalism enhancement can be done through several professionalism development activities like training and seminar. Besides that, a headmaster also has an important role to create a relationship with the teacher because the leadership style of a headmaster also has an impact on teacher performance.

Furthermore, achievement motivation also has a really essential role to create teacher professionalism and performance. That is why; it is a must that a headmaster must always create a comfortable and conducive school situation, so that teacher can be supported to always have good work.

This research only describes a relation between the headmaster leadership, teacher professionalism and 
performance, and the achievement motivation quantitatively. It means that there is a chance for the other researchers to dig further by using a qualitative approach to identify what the things that are wanted by the teachers so that their performance and achievement motivation can be increased to make them become a professionaleducator. Besides that, the next researcheris also able todothesame research by adding the students' achievement variable. It is because this research is not discussing a relation between the headmaster leadership, teacher professionalism, achievement motivation, teacher performance with the student's achievement.

\section{Acknowledgment}

Authors thanks to Master of Education Management Program, Lambung Mangkurat University, North Banjarmasin, 70124, South Kalimantan for supporting this research.

\section{References}

Ahmed, M., Hussain, I., Ahmed, M., Ahmed, S., \& Din, M. Q. (2012). A study of the factors affecting the professional performance of teachers at higher education level in khyber pakhtunkhwa. Academic Research International, 2(2), 336-34I.

Akuoko, K. O., Dwumah, P., \& Baba, W. M. (20I2). Teachers' Motivation and Quality Education Delivery: Study of Public Basic Schools in Tamale Metropolis in Ghana. International Journal of Social Science \& Interdisciplinary Research, I(I2), 29-46.

Batool, S., Tahir, T., \& Habib, M. (2018). Relationship of Teachers' Professional Competence and Achievement of Students at University Level. Turkish Journal of Teacher Education, 7(I), 50-60.

Cansoy, R., \& Parlar, H. (2017). Examining the Relationships Between the Level of Schools for Being Professional Learning Communities and Teacher Professionalism. Malaysian Online Journal of Educational Sciences, 13-27.

Chamundeswari, S. (2013). Job Satisfaction and Performance of School Teachers. International Journal of Academic Research in Business and Social Sciences, 3(5), 420428.

Chen, Y.-G. (2017). ExploringDifferences from Principals' Leaderships and Teachers' Teaching Performances in Public and Private
Schools. The Journal of International Management Studies, I2(2), 65-8I.

Darling-Hammond, L. (2000). Teacher Quality and Student Achievement: A Review of State Policy Evidence. Education Policy Analysis Archives, 8(I), I-44.

Eyal, O., \& Roth, G. (20I I). Principals' leadershipand teachers' motivation: Self-determination theory analysis. Journal of Educational Administration, $\quad 49(3), \quad 256-275$. doi:I0.I I08/0957823IIIII29055

Gichuru, L. M., \& Ongus, R. W. (2016). Effect of Teachers Quality on Students Performace in Mathematics in Primary 6 National Examination: A Survey of Private Primary Schools in Gasabo Distric, Kigali CIty, Rwanda. International Journal of Education and Research, 4(2), 237-260.

Gore, J., Lloyd, A., Smith, M., Bowe, J., Ellis, H., \& Lubans, D. (2017). Effects of professional development on the quality of teaching: Results from a randomised controlled trial of Quality Teaching Rounds. Teaching and Teacher Education, 68, 99-II3. doi:https://doi.org/I0.1016/j.tate.2017.08 .007

Gultom, H. G., Siburian, P., \& Purba, S. (2017). The effect of Headmaster's supervision, Work Satisfaction, Work Motivation towards Teacher Performance in Private Junior High School at Medan Perjuangan sub-district Medan City. IOSR Journal of Research \& Method in Education, 7(5), I-7. doi:10.9790/7388-0705010I07

Hamalik, O. (2003). Perencanaan Pengajaran berdasarkan Pendekatan Sistem. Yogyakarta: Andi Offset.

Hao, M. J., \& Yazdanifard, R. (2015). How Effective Leadership can Facilitate Change in Organizations through Improvement and Innovation. Global Journal of Management and Business Research: Administration and Management, I5(9), I-7.

Hasbay, D., \& Altındag, E. (2018). Factors that Affect the Performance of Teachers Working at Secondary-Level Education. Academy of Educational Leadership Journal, 22(I), I-I9.

Hasbullah, R., \& Moeins, A. (2017). The influnce of professionalism, achievement motivation and empowerment against the work discipline and its implication on teacher performance: 
empirical study on high school teachers in karawang regency. International Journal of Business andCommerce, 5(6), 18-36.

Iliya, A., \& Ifeoma, L. G. (2015). Assessment of Teacher Motivation Approaches in the Less Developed Countries. ournal of Education and Practice, 6(22), I0-I7.

Ishola, A. A., Adeleye, S. T., \& Tanimola, F. A. (2018). Impact of Educational, Professional Qualification and Years of Experience on Accountants' Job Performance. Journal of Accounting and Financial Management, Vol. 4 (I), 32-44. doi:I0.528I/zenodo.I2I0796

Kanfer, R., Frese, M., \& Johnson, R. E. (2017). Motivation Related to Work: A Century of Progress. Journal of Applied Psychology, IO2(3), 338-355. doi:I0.1037/ap10000I33

Kirimi, F. K., Gikunda, R. M., Obara, J., \& Kibett, J. (2013). Influence of Selected Motivational Factors on the Performance of Secondary School Agriculture Teachers in Imenti South District, Kenya. International Journal of Education and Research, I(6), I-I6.

Kola, A. J., \& Sunday, O. S. (2015). A Review of Teachers' Qualifications and Its Implication on Students' Academic Achievement in Nigerian Schools. International Journal of Educational Research and Information Science, 2(2), I0-I5.

Kotur, B. R., \& Anbazhagan, S. (2014). Education and Work-Experience-Influence on the Performance. OSR Journal of Business and Management, I6(5), I04-IIO. Retrieved from www.iosrjournals.org

Kumalasari. (2006). Kompetensi Guru. Bandung: PT RinekaCipta

Kumari, K., \& Qasim, S. (2015). A Study of Achievement Motivation in Relation to Academic Achievement of Higher Secondary Students. Indo-Indian Journal of Social Science Researches, II(I), 56-59.

Linda. (2004). Perilaku Organisasi. Yogyakarta: GadjahMada University Press.

McClelland, D.C. (1987). Human Motivation. New York: Cambrige University Press.

Mahmoudi, G., Rostami, F. H., Mahmoudjanloo, S., \& Jahani, M. A. (2017). Relationship of Employees' Achievement Motivation and Quality of Working Life with Their Selfefficacy at Selected Hospitals with a Multi- group Analysis: Moderating Role of Organizational Ownership. Materia Socio Medica, 29(4), 237-24I. doi:I0.5455/msm.20I7.29.237-24I

Makovec, D. (2018). The Teachers' Role and Professional Development. International Journal of Cognitive Research in Science, Engineering and Education, 6(2), 33-45.

Martaniah. (1998). Motivasi untuk Berprestasi. Jakarta: Quantum teaching

Novozhenina, A., \& Pinzón, M. M. (2018). Impact of a Professional Development Program on EFL Teachers' Performance. How, 25(2), II3-I28.

Rahbi, D. A., Khalid, K., \& Khan, M. (2017). The Effects of Leadership Styles on Team Motivation. Academy of Strategic Management Journal, I6(2), I-I4.

Renata, Wardiah, D., \& Kristiawan, M. (2018). The Influence Of Headmaster's Supervision And Achievement Motivation On Effective Teachers. International Journal of Scientific and Technology Research, 7(6), 44-49.

Rubayhan, J., \& Sowiyah. (2018). Reaction Teacher Achievement Motivation on Teacher Pedagogic Competence at Primary Schools. IOSR Journal of Research \& Method in Education, 8(5), 35-39.

Sahenk, S. S. (2010). Characteristics of the headmasters, teachers and students in an effective school. Procedia Social and Behavioral Sciences, 2, 4298-4304. doi:I0.I016/j.sbspro.2010.03.682

Selamat, N., Samsu, N. Z., \& Kamalu, N. S. (2013). The Impact of Organizational Climate on Teachers' Job Performance. Educational Research, 2(I), 7I-82. doi:10.5838/erej.2013.21.06

Simanjuntak, Payaman, J. (2005). Manajemen dan Evaluasi Kinerja. Jakarta: Lembaga Penertbit Fakultas Ekonomi Uneversitas Indonesia.

Sivakumar, R. (2016). Achievement Motivation of Teachers Trainee in Colleges of Education. Journal of Contemporary Educational Research and Innovations, 6(5), I80-I86.

Suhaimi. (2018). Hubungan Peran Kepala Sekolah dan Sikap terhadap Profesi Guru dengan Prestasi Kerja Guru SMA Negeri di Kabupaten Hulu Sungai Selatan. Program Magister Manajemen Pendidikan Universitas Lambung Mangkurat. 
Suriansyah, A. (2014). Hubungan Budaya Sekolah, Komunikasi, dan Komitmen Kerja terhadap Kinerja Guru Sekolah Dasar Negeri. Program Magister ManajemenPendidikan Universitas Lambung Mangkurat.

Susanto, A. (2016). Manajemen Peningkatan Kinerja Guru. Jakarta: Prenada media Group.

Taniredja. T., dkk. (20I5). Guru yang Profesional. Bandung: Alfabeta.

Taştan, S. B., Davoudi, S. M., Masalimova, A. R., Bersanov, A. S., Kurbanov, R. A., Boiarchu, A. V., \& Pavlushin, A. A. (2018). The Impacts of Teacher's Efficacy and Motivation on Student's Academic Achievement in Science Education among Secondary and High School Students. EURASIA Journal of Mathematics, Science and Technology Education, I4(6), 23532366.

Tehseen, S., \& Hadi, N. U. (2015). Factors Influencing Teachers' Performance and Retention. Mediterranean Journal of Social Sciences, $\quad 6(\mathrm{I}), \quad 233-244$. doi:I0.590I/mjss.20I5.v6nIp233

Undang-Undang No. 20. Tahun 2003. (2009). Sistem Pendidikan Nasioanal (SISDIKNAS). Bandung: Citra Umbara.
Undang-Undang Guru dan Dosen Tahun 2005 tentang Guru dan Dosen

Uno, H. \& Lamatenggo, N. (2015) Tugas Guru dalam Pembelajaran, Aspek yang Memengaruhi. Jakarta: BumiAksara.

Utami, N. (2003) Kualitas dan Profesionalisme Guru. http://www.pikiranrakyat.com/cetak/102/15/0802/htm. Diunduh I2 Januari 2018.

Wahab, J. A., Fuad, C. F., Ismail, H., \& Majid, S. (20I4). Headmasters' Transformational Leadership and Their Relationship with Teachers' Job Satisfaction and Teachers' Commitments. International Education Studies, $\quad 7(\mathrm{I3}), \quad$ 40-48. doi:I0.5539/ies.v7nI3p40

Wahyuddin, W. (2017). Headmaster Leadership and Teacher Competence in Increasing Student Achievement in School. International Education Studies, IO(3), 215-226.

Zazim, N. (2004). Gerakan Menata Mutu Pendidikan, Teori dan Aplikasinya. Yogyakarta: Ar-Ruzz Media 